\title{
Health behaviors of postmenopausal women
}

\author{
Maria Jasińska' ${ }^{1}$ Katarzyna Żułtak-Bączkowskaa ${ }^{1}$, Bożena Mroczek ${ }^{1}$, Artur Kotwas ${ }^{1}$, \\ Ewa Kemicer-Chmielewska ${ }^{1}$, Beata Karakiewicz ${ }^{1}$, Andrzej Starczewski ${ }^{2}$
}

${ }^{1}$ Zakład Zdrowia Publicznego, Wydział Nauk o Zdrowiu, Pomorski Uniwersytet Medyczny w Szczecinie

${ }^{2}$ Klinika Ginekologii i Uroginekologii, Pomorski Uniwersytet Medyczny w Szczecinie

\begin{abstract}
Introduction: Health status and health-related quality of life of postmenopausal women are issues, which nowadays pose a serious challenge to many domains of science. Climacteric symptoms which occur at this stage of life, lower its quality and make a negative contribution to self-reported health status, are mostly observed in a particular group of women. Evaluation of health behaviors performed using a standardized questionnaire, the Health Behavior Inventory ( $\mathrm{HBI}$ ), may help establish a comprehensive diagnosis of women's health, and thus select effective interventions. A systemic approach to menopause assumes that full fitness of women and good quality of their lives can be maintained not only by means of pharmacotherapy but also other forms of action, especially health education oriented towards changes in the lifestyle and promotion of healthy behaviors.

Aim of the study is to perform a HBI-based assessment of women's health behaviors in such categories as healthy eating habits ( $\mathrm{HEH})$, preventive behaviors (PB), positive mental attitudes (PMA), and health practices (HP).

Material and methods: The study involved 151 healthy postmenopausal women. A research tool was a standardized questionnaire, the Health Behavior Inventory (HBI).

Results: The surveyed women obtained $70 \%$ of the maximum score on average, which suggests a medium level of health behaviors in this group. The levels of health behaviors in the categories of positive mental attitudes and health practices significantly differed between older women and their younger counterparts (higher levels were observed among older respondents). There were also significant differences in the levels of healthy behaviors between women with secondary and higher education (those better educated declared healthy behaviors more often). There was no correlation between the level of health behaviors and the BMI of the surveyed women.

Conclusions: Older women attached greater importance to positive mental attitudes, and so they avoided tension, stress and depressing situations. They also attached more weight to health practices (HP), i.e. the number of hours devoted to sleeping, resting and physical activity. The main determinant of a healthy lifestyle was higher education.
\end{abstract}

Key words: menopause, health behaviors, quality of life.

\section{Introduction}

Demographic data of most countries, including Poland, show a stable trend in extending people's average lifespan. The issue of health and quality of life of the elderly is becoming a major concern of health policy. At present, Polish women's average life expectancy is 80.9 years, with menopause occurring at the age of 51.2 [1-3]. These data indicate the fact that the postmenopausal period constitutes a considerable part of women's lives. Processes of diminishing of estrogen synthesis and secretion, which start at this age, cause a number of ailments negatively affecting postmenopausal women's self-reported health status and quality of their lives $[4,5]$.
Also, very often only the mass media and not professional healthcare workers are the main source of knowledge about the symptoms and methods of coping in this period. Hence women's knowledge is superficial, mainly oriented to risks and harmful effects of hormonal therapy. Therefore, it is crucial that the youngest women should have a chance to gain solid knowledge about the postmenopausal period in order to guide them on the potential possibilities and new life perspectives and constant personal development [6-8]. Thus promoting health, health education and above all health behaviors on a daily basis are the key issues for women to maintain health and good quality of life. Reliable evaluation of health behaviors performed using standardized tools should be preliminary practice [9]. 


\section{Aim of the study}

The aim of this study is to define levels of postmenopausal women's health behaviors in respect of healthy eating habits $(\mathrm{HEH})$, preventive behaviors $(\mathrm{PB})$, positive mental attitudes (PMA), and health practices (HP).

\section{Material and methods}

The study included 151 healthy women who did not menstruate for at least a year. Participation was voluntary. Volunteers entered the study after they read the invitation and gained additional information about the study profile either at their GP's or gynecologist's surgeries. Criteria of exclusion were diagnosed chronic diseases such as diabetes, cancer, liver diseases, renal failure, hypertension, and thyroid disease. A standardized questionnaire assessing health behavior inventory $(\mathrm{HBI})$ was used; women filled it out themselves or assisted by the researchers. Selected sociometric data were collected on the basis of the author's own questionnaire. It included such variables as age, domicile, education, marital status and professional activity. The subjects were divided per age into a younger group (aged 42-55) and an older group (aged 56-69). The body mass index of each woman was also calculated; the proper body weight $(\mathrm{P})$ was assumed at $\mathrm{BMI}$ $=18.5-24.9$, excess weight $(\mathrm{E})$ at $\mathrm{BMI}=25.0-29.9$, and obesity $(\mathrm{O})$ at $\mathrm{BMI}>30$.

The study was conducted upon the consent of the Bioethical Commission of the Pomeranian Medical University in Szczecin.

In the $\mathrm{HBI}$ questionnaire women marked how often they performed health-related activities, assessing each behavior according to a five-grade scale from "hardly ever", "rarely", "sometimes", "frequently" up to "almost always". Results related to the general index of health behaviors (HB) and indices related to particular behavior were further divided into four categories: healthy eating habits $(\mathrm{HEH})$, taking into consideration types of consumed food, e.g. wholemeal bread, vegetables, fruit; preventive behaviors (PB), such as following health recommendations, gaining information about health and illness; positive mental attitudes (PMA), oriented towards avoidance of strong emotions, stress, tension and depressing situations; and health practices
(HP), connected with the number of hours devoted to sleeping, recreation or physical activity forms.

The questionnaire enables assessment of the general index of health behavior inventory $(\mathrm{HBI})$, whose value may range between 24 and 120 points. The higher score the higher level of declared health behaviors.

The study compared indices of health behaviors of women in particular categories related to their age, education, BMI and marital status. Statistical analysis of the results obtained was carried out using STATISTICA. $\mathrm{PL}$, version 9.

\section{Results}

The surveyed women were aged between 42 and 69 . The mean age (standard deviation) was 55.5 (SD 4.7). Women aged 42-55 ( $n=78)$ constituted a larger group, i.e. $51.7 \%$. Respondents aged 56-69 amounted to $48.3 \%(n=73)$. The vast majority of those surveyed, $93.4 \%(n=141)$, were residents of cities with a population over 100000 . Most of the subjects were professionally active, i.e. $67.5 \%(n=98)$; out of the remaining respondents: $7.3 \%(n=11)$ did not work, $19.2 \%$ $(n=29)$ were occupational pensioners and $6 \%(n=9)$ received disability pension. Nearly half of respondents, i.e. $47.7 \%(n=72)$ declared to have secondary education, slightly fewer were highly educated $(43.7 \% ; n=66)$ and 12 women $(7.9 \%)$ were vocationally trained. One respondent had primary education. The most numerous group was made up of married women $(74 \% ; n=111)$, whereas $13.9 \%(n=21)$ were divorced; there were even fewer widows $-6.6 \%(n=10)$ and the smallest group, $0.6 \%(n=9)$, consisted of singles.

The above results show that in the global evaluation of health behaviors for the study group of women, the arithmetic mean (standard deviation) of general HBI was 84.3 (11.8), median: 85.

Analyzing particular categories of health behaviors, those surveyed assessed positive mental attitudes at the highest level, i.e. $\bar{\chi} 3.65$ (0.70). Respondents paid the least attention to health practices, where $\bar{\chi} 3.33$ (0.63), median: 3.33 .

According to the obtained results, statistical differences between the two age groups concerned health behavior index in terms of positive mental attitudes $(p=0.036)$ and health practices $(p=0.004)$. In these respects older

Table I. Mean results of health behaviors in the study group

\begin{tabular}{llcc}
\hline Health behaviors & Min.-Max. & Me $\left(\mathbf{Q}_{1} ; \mathbf{Q}_{3}\right)$ & $\bar{\chi}(\mathbf{s})$ \\
\hline General index of health behavior inventory (HBI) & $50-120$ & $85(78.00 ; 92.00)$ & $84.3(11.8)$ \\
\hline 1. $\quad$ Level of healthy eating habits (HEH) & $1.66-5$ & $3.5(3.00 ; 4.16)$ & $3.51(0.72)$ \\
\hline 2. $\quad$ Level of preventive behaviors (PB) & $1.16-5$ & $3.5(2.83 ; 4.00)$ & $3.41(0.78)$ \\
\hline 3. $\quad$ Level of positive mental attitudes (PMA) & $2.33-5$ & $3.66(3.16 ; 4.16)$ & $3.65(0.70)$ \\
\hline 4. $\quad$ Level of health practices (HP) & $1.66-5$ & $3.33(2.83 ; 3.83)$ & $3.33(0.63)$ \\
\hline
\end{tabular}


Table II. Characteristics of health behaviors distribution in the study group in respect of selected sociometric variables

\begin{tabular}{|c|c|c|c|c|}
\hline Characteristics of distribution & Healthy eating habits & Preventive behaviors & Positive mental attitudes & Health practices \\
\hline & \multicolumn{4}{|c|}{ Age $42-55$ years $(n=78)$} \\
\hline \multirow[t]{2}{*}{$\begin{array}{l}\min .-\max . \\
\operatorname{Me}\left(Q_{1} ; Q_{3}\right) \\
\bar{\chi}(s)\end{array}$} & $\begin{array}{c}1.66-5 \\
3.33(2.87 ; 4.00) \\
3.43(0.75) \\
\end{array}$ & $\begin{array}{c}1.16-5 \\
3.50(2.66 ; 3.83) \\
3.31(0.79) \\
\end{array}$ & $\begin{array}{c}2.33-4.83 \\
3.50(3.16 ; 4.00) \\
3.54(0.66)\end{array}$ & $\begin{array}{c}1.66-4.66 \\
3.25(2.66 ; 3.62) \\
3.19(0.67)\end{array}$ \\
\hline & \multicolumn{4}{|c|}{ Age $56-69$ years $(n=73)$} \\
\hline $\begin{array}{l}\min .-\max . \\
\operatorname{Me}\left(Q_{1} ; Q_{3}\right) \\
\bar{\chi}(s)\end{array}$ & $\begin{array}{c}2.33-5 \\
3.66(3.00 ; 4.16) \\
3.60(0.69)\end{array}$ & $\begin{array}{c}2.00-5 \\
3.66(3.00 ; 400) \\
3.52(0.76) \\
\end{array}$ & $\begin{array}{c}2.33-5 \\
3.83(3.33 ; 4.33) \\
3.76(0.73) \\
\end{array}$ & $\begin{array}{c}2.16-5 \\
3.50(3.16 ; 3.83) \\
3.47(0.55)\end{array}$ \\
\hline \multirow[t]{2}{*}{$\begin{array}{l}\text { significance level } \\
\text { Mann-Whitney U test }\end{array}$} & 0.16 & 0.11 & 0.036 & 0.004 \\
\hline & \multicolumn{4}{|c|}{ Vocational training $(n=12)$} \\
\hline \multirow[t]{2}{*}{$\begin{array}{l}\min .-\max . \\
\operatorname{Me}\left(Q_{1} ; Q_{3}\right) \\
\bar{\chi}(s)\end{array}$} & $\begin{array}{c}2.33-4.50 \\
3.50(2.96 ; 4.04) \\
3.44(0.72)\end{array}$ & $\begin{array}{c}2.50-4.83 \\
3.91(3.29 ; 4.37) \\
3.83(0.74)\end{array}$ & $\begin{array}{c}3.16-5 \\
4.24(3.71 ; 4.54) \\
4.14(0.62)\end{array}$ & $\begin{array}{c}2.33-4.50 \\
3.50(2.66 ; 400) \\
3.43(0.71)\end{array}$ \\
\hline & \multicolumn{4}{|c|}{ Secondary education $(n=72)$} \\
\hline \multirow[t]{2}{*}{$\begin{array}{l}\min .-\max . \\
\operatorname{Me}\left(Q_{1} ; Q_{3}\right) \\
\bar{X}(s)\end{array}$} & $\begin{array}{c}1.66-5 \\
3.25(2.83 ; 4.00) \\
3.38(0.73) \\
\end{array}$ & $\begin{array}{c}1.16-5 \\
3.50(2.66 ; 3.83) \\
3.39(0.77) \\
\end{array}$ & $\begin{array}{c}2.33-5 \\
3.50(3.16 ; 4.16) \\
3.51(0.71) \\
\end{array}$ & $\begin{array}{c}1.66-5 \\
3.25(2.83 ; 3.66) \\
3.23(0.59)\end{array}$ \\
\hline & \multicolumn{4}{|c|}{ Higher education $(n=66)$} \\
\hline $\begin{array}{l}\min .-\max . \\
\operatorname{Me}\left(Q_{1} ; Q_{3}\right) \\
\bar{X}(\mathrm{~s})\end{array}$ & $\begin{array}{c}2.16-5 \\
3.66(3.16 ; 4.33) \\
3.69(0.69) \\
\end{array}$ & $\begin{array}{c}1.83-5 \\
3.42(2.75 ; 4.00) \\
339(0.77)\end{array}$ & $\begin{array}{c}2.33-4.83 \\
3.75(3.33 ; 4.16) \\
3.72(0.68)\end{array}$ & $\begin{array}{c}2.00-4.66 \\
3.50(3.00 ; 3.83) \\
3.40(0.65)\end{array}$ \\
\hline \multirow[t]{2}{*}{$\begin{array}{l}\text { significance level } \\
\text { Mann-Whitney } U \text { test }\end{array}$} & \multicolumn{4}{|c|}{$\begin{array}{c}\text { vocational vs. secondary } 0.76 \\
\text { vocational vs. higher } 0.30 \\
\text { secondary vs. higher } 0.012\end{array}$} \\
\hline & \multicolumn{4}{|c|}{ BMI, P - proper weight $(n=57)$} \\
\hline \multirow[t]{2}{*}{$\begin{array}{l}\min .-\max . \\
\operatorname{Me}\left(Q_{1} ; Q_{3}\right) \\
\bar{\chi}(s)\end{array}$} & $\begin{array}{c}2.16-4.83 \\
3.33(3.00 ; 4.16) \\
3.47(0.74) \\
\end{array}$ & $\begin{array}{c}1.16-4.83 \\
3.50(2.66 ; 4.00) \\
3.35(0.83) \\
\end{array}$ & $\begin{array}{c}2.33-5 \\
3.50(3.16 ; 4.16) \\
3.60(0.74) \\
\end{array}$ & $\begin{array}{c}2.00-4.5 \\
3.33(2.66 ; 3.66) \\
3.25(0.66)\end{array}$ \\
\hline & \multicolumn{4}{|c|}{ BMI, E - excess weight $(n=65)$} \\
\hline \multirow[t]{2}{*}{$\begin{array}{l}\min .-\max \\
\operatorname{Me}\left(Q_{1} ; Q_{3}\right) \\
\bar{\chi}(s)\end{array}$} & $\begin{array}{c}1.66-5 \\
3.50(3.00 ; 4.00) \\
3.53(0.73) \\
\end{array}$ & $\begin{array}{c}2.00-5 \\
3.66(3.04 ; 4.00) \\
3.51(0.70) \\
\end{array}$ & $\begin{array}{c}2.33-5 \\
3.66(3.33 ; 4.16) \\
3.68(0.68) \\
\end{array}$ & $\begin{array}{c}1.66-5 \\
3.33(2.83 ; 3.83) \\
3.39(0.62) \\
\end{array}$ \\
\hline & \multicolumn{4}{|c|}{ BMI, O - obesity $(n=29)$} \\
\hline $\begin{array}{l}\min .-\max . \\
\operatorname{Me}\left(Q_{1} ; Q_{3}\right) \\
\bar{\chi}(s)\end{array}$ & $\begin{array}{c}2.33-5 \\
3.66(3.00 ; 4.16) \\
3.57(0.69) \\
\end{array}$ & $\begin{array}{c}2.00-5 \\
3.16(2.66 ; 3.83) \\
3.32(0.83) \\
\end{array}$ & $\begin{array}{c}2.33-4.84 \\
3.66(3.16 ; 4.33) \\
3.68(0.70) \\
\end{array}$ & $\begin{array}{c}2.33-4.66 \\
3.33(2.83 ; 3.83) \\
3.33(0.59) \\
\end{array}$ \\
\hline \multirow[t]{2}{*}{$\begin{array}{l}\text { significance level } \\
\text { proper BMI vs. excess weight } \\
\text { proper BMI vs. obesity } \\
\text { BMI excess weight vs. obesity }\end{array}$} & $\begin{array}{l}0.63 \\
0.58 \\
0.85\end{array}$ & $\begin{array}{l}0.30 \\
0.77 \\
0.23\end{array}$ & $\begin{array}{l}0.48 \\
0.65 \\
0.91 \\
\end{array}$ & $\begin{array}{l}0.16 \\
0.53 \\
0.65 \\
\end{array}$ \\
\hline & \multicolumn{4}{|c|}{ Marital status - single $(n=9)$} \\
\hline \multirow[t]{2}{*}{$\begin{array}{l}\min .-\max . \\
\operatorname{Me}\left(\mathrm{Q}_{1} ; \mathrm{Q}_{3}\right) \\
\bar{\chi}(\mathrm{s})\end{array}$} & $\begin{array}{c}3.00-4.33 \\
3.50(3.33 ; 3.83) \\
3.65(0.45) \\
\end{array}$ & $\begin{array}{c}3.16-5 \\
3.66(3.50 ; 4.00) \\
3.79(0.53) \\
\end{array}$ & $\begin{array}{c}2.33-3.83 \\
3.50(2.50 ; 3.66) \\
3.18(0.61) \\
\end{array}$ & $\begin{array}{c}2.83-4.33 \\
3.50(3.33 ; 4.00) \\
3.55(0.49) \\
\end{array}$ \\
\hline & \multicolumn{4}{|c|}{ Marital status - married $(n=111)$} \\
\hline \multirow[t]{2}{*}{$\begin{array}{l}\min .-\max . \\
\operatorname{Me}\left(Q_{1} ; Q_{3}\right) \\
\bar{X}(s)\end{array}$} & $\begin{array}{c}2.33-5 \\
3.50(3.00 ; 4.00) \\
3.49(0.70) \\
\end{array}$ & $\begin{array}{c}1.83-5 \\
3.50(2.99 ; 3.83) \\
3.41(0.74)\end{array}$ & $\begin{array}{c}2.33-5 \\
3.66(3.25 ; 4.75) \\
3.63(0.69) \\
\end{array}$ & $\begin{array}{c}2.16-4.66 \\
3.33(2.83 ; 3.66) \\
3.28(0.61)\end{array}$ \\
\hline & \multicolumn{4}{|c|}{ Marital status - widows $(n=10)$} \\
\hline \multirow[t]{2}{*}{$\begin{array}{l}\min .-\max . \\
\operatorname{Me}\left(Q_{1} ; Q_{3}\right) \\
\bar{\chi}(s)\end{array}$} & $\begin{array}{c}2.83-5 \\
3.83(3.33 ; 4.25) \\
3.78(0.72) \\
\end{array}$ & $\begin{array}{c}2.33-5 \\
3.50(2.99 ; 3.83) \\
3.43(0.83) \\
\end{array}$ & $\begin{array}{c}2.33-5 \\
3.66(3.25 ; 4.75) \\
3.76(0.89) \\
\end{array}$ & $\begin{array}{c}2.33-5 \\
3.66(3.33 ; 3.91) \\
3.53(0.80) \\
\end{array}$ \\
\hline & \multicolumn{4}{|c|}{ Marital status - divorced $(n=21)$} \\
\hline $\begin{array}{l}\min .-\max . \\
\operatorname{Me}\left(Q_{1} ; Q_{3}\right) \\
\bar{X}(\mathrm{~s})\end{array}$ & $\begin{array}{c}1.66-4.66 \\
3.83(2.66 ; 4.16) \\
3.46(0.93)\end{array}$ & $\begin{array}{c}1.16-4.66 \\
3.16(2.33 ; 4.16) \\
3.27(1.02)\end{array}$ & $\begin{array}{c}2.33-4.83 \\
4(3.50 ; 4.33) \\
3.89(0.64) \\
\end{array}$ & $\begin{array}{c}1.66-4.5 \\
3.50(3.00 ; 3.83) \\
3.38(0.72)\end{array}$ \\
\hline $\begin{array}{l}\text { significance level } \\
\text { single vs. married } \\
\text { single vs. widows } \\
\text { single vs. divorced } \\
\text { married vs. widows } \\
\text { married vs. divorced } \\
\text { widows vs. divorced }\end{array}$ & $\begin{array}{l}0.44 \\
0.90 \\
0.87 \\
0.23 \\
0.95 \\
0.40\end{array}$ & $\begin{array}{l}0.19 \\
0.36 \\
0.35 \\
0.94 \\
0.80 \\
0.88\end{array}$ & $\begin{array}{l}0.08 \\
0.21 \\
0.015 \\
0.66 \\
0.11 \\
0.69\end{array}$ & $\begin{array}{l}0.17 \\
0.97 \\
0.72 \\
0.26 \\
0.27 \\
0.86\end{array}$ \\
\hline
\end{tabular}


women (56-69) showed a higher level of health behaviors. Eating habits as well as the range of preventive behaviors were similar in both groups and no significant differences were noted.

The comparison of general $\mathrm{HBI}$ scores in relation to education of those surveyed indicated a significant difference between levels of health behaviors among women with secondary vs. higher education ( $p=0.012$ ). Those better educated declared a significantly wider scope of health behaviors.

However, this study did not show any correlation between the levels of health behaviors and the BMI of the surveyed women. Scores obtained in the questionnaire by women with the proper BMI and those with excess weight or obesity did not differ significantly.

The analysis of levels of health behaviors in relation to marital status of the subjects indicated a significant difference between unmarried women (single) and the divorced $(p=0.015)$. The scores were higher among the divorced women.

\section{Discussion}

The result obtained by the authors of the questionnaire related to general health behaviors inventory in a group of menopausal women (original terminology) was 86 (12.7). In standardizing studies the researchers gained the highest results in a group of people suffering e.g. from diabetes (92.44 points) and in women with pregnancy complications (90.18 points) [9]. It may indicate that practicing health behaviors concerns to a greater extent diseased people, who sustained an evident health loss. So the surveyed women did not interpret their state as abnormal and thus did not feel the need to take special care of their health. Such an opinion is certainly wrong as healthy lifestyle may lessen the intensity of menopausal symptoms experienced and therefore improve women's psycho-social and professional functioning [10-12]. An exceptional sphere of health dimension was positive mental attitude in which the study group scored the best. This may prove that it is the mental state of women at this stage of life that troubles them the most. Experiencing strenuous symptoms which hamper daily as well as professional life motivates women, especially those better-off and highly educated, to take actions to minimize the symptoms. Currently, administering menopausal hormone therapy (MHT) is the most effective way to reduce the main menopausal ailments caused by lowered concentration of female hormones in women at this age [13]. The climacteric symptoms lower the quality of women's life and make a negative contribution to their self-reported health status. This phenomenon is mostly observed in a particular group of women. According to Mishira et al., it concerns a specific risk group of women, single, badly off, convinced that menopause is an unfavorable change in their life and health state [5]. In this study, significant age-related differences referred to positive mental attitudes and health practices. It may indicate that in ageing women, the most serious problem is their mental well-being. However, changes to the lifestyle, introducing certain non-pharmacological methods such as psychotherapy, acupuncture, physical and relaxing exercises, maintaining normal BMI, avoiding stimulants also contribute to reducing negative circummenopausal symptoms $[14,15]$. Study results show that an increased risk of the other illnesses, which affect old-age people more frequently, is accompanied by greater interest in health behaviors. Lack of motivation to control the BMI is another unfavorable phenomenon which may additionally adversely influence the health of the surveyed women.

According to Twiss et al., women do not lead a healthy lifestyle but one which does not promote health priorities due to numerous negative effects, and it is primarily visible in their improper diet, failing to follow health recommendations, refusing to undergo preventive routine exams or lack of physical activity [13]. Study results confirm prevalence of improper lifestyle in the population of postmenopausal women. It is mainly manifested by the lack of proper eating habits or preventive behaviors. Single women (unmarried, divorced ones and widows) were more involved in their health, which may be a sign of resignation from their own needs, including health, among the married ones. The results of this study identify a risk group being younger women with secondary education, living in a relationship.

\section{Conclusions}

Older women attached greater importance to positive mental attitudes, and so they avoided tension, stress and depressing situations. They also attached more weight to health practices (HP) i.e. the number of hours devoted to sleeping, resting and physical activity. The main determinant of a healthy lifestyle was higher education.

\section{Disclosure}

Authors report no conflicts of interest.

\section{References}

1. www.gus.pl; access: $9.10 .2011 \mathrm{r}$

2. Kaczmarek M. The timing of natural menopause in Poland and associated factors. Maturitas 2007; 57: 139-153.

3. Kaczmarek M. Określenie wieku menopauzy naturalnej w populacji polskich kobiet. Prz Menopauz 2007; 11: 77-82.

4. Skrzypulec V, Naworska B, Drosdzol A. Analiza wpływu objawów klimakterycznych na funkcjonowanie i jakość życia kobiet w okresie okołomenopauzalnym. Prz Menopauz 2007; 11: 96-101. 
5. Bielawska-Batorowicz E. Stres, obawy i przekonania dotyczące menopauzy a obniżony nastrój u kobiet w wieku 45-55 lat. Próba weryfikacj zmodyfikowanego psychospołecznego modelu depresji w okresie okotomenopauzalnym. Prz Menopauz 2006; 10: 68-74.

6. Mishira G, Kuh D. Perceived change in quality of life during the menopause. Soc Sci Med 2006; 62: 93-102.

7. Marczyńska-Wdówik A. Rola wybranych zasobów osobistych w radzeniu sobie ze stresem $u$ kobiet $w$ okresie klimakterium. Psychiatr Pol 2006; 2: 301-310.

8. Welton A, Vickers $M$, Kim J, et al. Health related quality of life after combined hormone replacement therapy: randomized controlled trial. BMJ 2008; 337: 1190-1199.

9. Synowiec-Piłat M. Wybrane społeczne wyznaczniki jakości życia 50-letnich Polek w kontekście ich sytuacji zdrowotnej. Prz Menopauz 2010; 14: 385-389.

10. Juczyński Z. Narzędzia pomiaru w promocji i psychologii zdrowia. Pracownia Testów Psychologicznych, Warszawa 2009; 110-116.

11. Rabiej M, Dmoch-Gajzlerska E, Andrzejewska A. Okres okołomeno pauzalny - zagrożenia zdrowotne; www.wydawnictwopzwl.pl, access 4.10.2011.
12. Gold EB, Sternfeld B, Kelsey JL, et al. Relation of demographic and lifestyle factors to symptoms in a multi-racial/ethnic population of women 40-55 years of age. Am J Epidemiol 2000; 152: 463-473.

13. Hickey M, Davis SR, Sturdee D. Treatment of menopausal symptoms: what shall we do now? Lancet 2005; 366: 409-421.

14. Twiss JJ, Wegner J, Hunter $M$, et al. Perimenopausal symptoms, quality of life, and health behaviors in users and nonusers of hormone therapy. J Am Acad Nurse Pract 2007; 19: 602-613.

15. Moilanen JM, Mikkola TS, Raitanen JA, et al. Effect of aerobic training on menopausal symptoms - a randomized controlled trial. Menopause 2012; 19: 691-696.

16. Im EO, Lee B, Chee W, et al. A national multiethnic online forum study on menopausal symptom experience. Nurs Res 2010; 59: 26-33.

17. Pluchino N, Bucci F, Cela V, et al. Menopause and mental well-being: timing of symptoms and timing of hormone treatment. Womens Health 2011; 7: 71-80 